DOI: $10.19195 / 2084-5065.46 .8$

\title{
Shadow banking a prawo karne gospodarcze
}

\author{
Piotr OCHMAN \\ Katedra Kryminologii i Nauk o Bezpieczeństwie \\ Wydział Prawa, Administracji i Ekonomii Uniwersytetu Wrocławskiego

\section{Uwagi wprowadzające}

Prawo karne powinno nadążać za występującą w różnych postaciach przestępczością i jej zmieniającymi się formami. Bieżący monitoring i ewaluacja istniejących rozwiązań karnoprawnych z punktu widzenia ich aktualności i adekwatności do zwalczania pojawiających się patologii gospodarczych stanowią wyznaczniki racjonalnej polityki kryminalnej. Nie każda jednak nowa tendencja pojawiająca się w gospodarce, nawet prima facie stwarzająca pozory patologii, wymaga ingerencji karnoprawnej. W zakresie kryminalizacji aktywności ekonomicznej konieczne jest zwłaszcza zapewnienie, aby „ultima ratio nie stawała się prima ratio" Subsydiarność prawa karnego gospodarczego rozumiana być może bowiem zarówno jako subsydiarność stanowienia prawa karnego gospodarczego $^{2}$, jak i subsydiarność jego stosowania ${ }^{3}$.

Obserwowane aktualnie patologiczne zachowania w sferze gospodarki są w polskiej rzeczywistości społecznej wciąż stosunkowo nowym zjawiskiem, które nie do końca spotyka się ze zdecydowaną, koherentną

1 W. Wolter, Granice i zakres prawa karania, „Państwo i Prawo” 1957, z. 2, s. 243.

2 S. Żółtek, Prawo karne gospodarcze $w$ aspekcie zasady subsydiarności, Warszawa 2009, s. 245 n.

3 Ibidem, s. 304 n.

Nowa Kodyfikacja Prawa Karnego 46, 2017

(C) for this edition by CNS 
(zarówno w aspekcie spójności systemowej wewnętrznej, jak i zewnętrznej) i racjonalną reakcją ze strony ustawodawcy karnogospodarczego ${ }^{4}$. Przykładów jest aż nadto. Wystarczy wspomnieć o podstawowych jakby się mogło wydawać — problemach interpunkcyjnych ustawodawcy wpływających na (niezasadne) ograniczenie zakresu kryminalizacji ${ }^{5}$, braku jednolitości w zakresie posługiwania się klauzulami odpowiedzialności zastępczej (klauzulami odpowiedzialności podmiotu zbiorowego) ${ }^{6}$, stosowaniu zbyt blankietowych (nawet kauczukowych) regulacji karnogospodarczych ${ }^{7}$, braku spójności w zakresie karania przejawów patologii gospodarczych o zbliżonym stopniu karygodności ${ }^{8}$, czy też dysfunkcyjności odpowiedzialności podmiotów zbiorowych za czyny zabronione pod groźbą kary 9 .

Zasygnalizowane zaledwie skrótowo i niewyczerpująco mankamenty aktualnego ustawodawstwa karnogospodarczego dziwią o tyle, że już przed laty J. Makarewicz słusznie zauważył, iż przyczyn przestępczości nie należy szukać w ,nędzy, ani w braku elementarnej oświaty, lecz w niskich pobudkach natury ludzkiej, które przy lepszych warunkach ekonomicznych i wyższym stopniu wykształcenia znajdą sobie upust

${ }^{4}$ Zob. J. Majewski, O przemyślany, spójny system sankcji karnych, [w:] Zagadnienia współczesnej polityki kryminalnej, red. T. Dukiet-Nagórska, Bielsko-Biała 2006, s. 54-63; R. Zawłocki, Kryminalizacja obrotu gospodarczego w Polsce, [w:] Zagadnienia wspótczesnej polityki kryminalnej..., s. 214-231.

${ }^{5}$ Chodzi o przepis art. 171 ust. 2 ustawy z dnia 29 sierpnia 1997 r. - Prawo bankowe (dalej jako: PrB), w którym doszło do błędu interpunkcyjnego (szerzej zob. J. Majewski, Przestępne użycie określeń „,bank” lub ,kasa”, „Prawo Bankowe” 2000, nr 5, s. 64; J. Majewski, [w:] Prawo karne gospodarcze, red. O. Górniok, Warszawa 2003, s. 283).

${ }^{6}$ Zob. przykładowo R. Zawłocki, Odpowiedzialność karna reprezentanta podmiotu zbiorowego, Warszawa 2013, s. 117-129; P. Ochman, Uwagi o klauzuli odpowiedzialności zastępczej za przestępstwa w pozakodeksowym prawie karnym gospodarczym, „Nowa Kodyfikacja Prawa Karnego” XXVII, 2011, s. 289-306.

${ }^{7}$ Np. regulacja dotycząca tajemnicy bankowej (zob. J. Majewski, W labiryncie tajemnicy bankowej (o pilnej potrzebie rewizji przepisów o tajemnicy bankowej), „Prawo Bankowe" 2001, nr 7/8, s. 39-52) bądź też znaczna część pozakodeksowych przestępstw gospodarczych (zob. przykładowo R. Zawłocki, [w:] Ustawa o ofercie publicznej i warunkach wprowadzania instrumentów finansowych do zorganizowanego systemu obrotu oraz o spółkach publicznych. Komentarz, red. T. Sójka, Warszawa 2010, s. 758).

8 P. Ochman, Karnoprawna ochrona podejmowania działalności finansowej, „Ruch Prawniczy, Ekonomiczny i Socjologiczny” 2016, z. 2, s. 170-171.

${ }^{9}$ Ibidem, s. 171-172.

Nowa Kodyfikacja Prawa Karnego 46, 2017

(C) for this edition by CNS 
w innej, bardziej wyrafinowanej formie"10. Teza ta wydaje się znajdować potwierdzenie w praktycznych przejawach przestępczości nowego typu $^{11}$. Aktualnie zresztą, także w Polsce, ujawniane są nowe afery gospodarcze, na tle sprawdzonych przykładów z początków transformacji ustrojowej $^{12}$, jak też stanowiące przejaw nowych możliwości, jakie daje rozwój gospodarczy ${ }^{13}$.

Gruntem szczególnie podatnym na występowanie różnego rodzaju patologii gospodarczych jest rynek finansowy. Do czynników kryminogennych przestępczości gospodarczej w tym obszarze, poza czynnikami kryminogennymi przestępczości gospodarczej w ogóle (ekonomicznymi oraz społeczno-kulturowymi - socjo-psychicznymi) ${ }^{14}$, zaliczyć można m.in. architekturę rynku finansowego, jego skomplikowany charakter, występowanie innowacji finansowych, masowość dokonywanych transakcji, często ponadnarodowy charakter, pokusę osiągnięcia ponadprzeciętnych zysków, asymetrię informacji, anonimowość uczestników czy brak potrzeby bezpośredniego kontaktu stron transakcji. Wzajemne powiązania występujące pomiędzy poszczególnymi segmentami rynku finansowego powodują, że jakiekolwiek naruszenie stabilności, bezpieczeństwa oraz zaufania do podmiotów działających w jego poszczególnych sektorach wiązać się może z powstaniem efektu domina (tzw. contagion effect), skutkującego powstaniem zagrożenia dla innych podmiotów tych segmentów, innych segmentów tego rynku, a w skrajnym przypadku dla systemów finansowych państw. Występowanie patologii w obszarze rynku finansowego związane jest także z zachowaniami, które w odbiorze zewnętrznym mogą stanowić przejaw zwyczajnych (stwarzających pozory legalności) działań związanych ze skomplikowanym charakterem czynności specyficznych dla tego rynku, brakiem elementu przemocy, a także

10 J. Makarewicz, Źródła przestępności, Lwów 1913, s. 16.

11 Zob. K. Schneider, Patologie i oszustwa gospodarcze po transformacji ustrojowej, Szczecin 2016, s. 39-56.

12 Np. sprawa Amber Gold.

13 Np. sprawa Warszawskiej Grupy Inwestycyjnej czy Interbrok.

14 Zob. szerzej O. Górniok, Przestepczość gospodarcza i jej zwalczanie, Warszawa 1994, s. 41; L. Wilk, Przestępczość gospodarcza — pojęcie, przyczyny, sprawcy, „Edukacja Prawnicza” 2012, nr 10, s. 14.

Nowa Kodyfikacja Prawa Karnego 46, 2017

(C) for this edition by CNS 
anonimowością ofiar ${ }^{15}$. Wskazane wyżej czynniki powodują, że często straty, które ponoszone są w związku z różnego rodzaju nadużyciami, mogą być trudne lub wręcz niemożliwe do oszacowania ${ }^{16}$. Jednocześnie nie może umykać z pola widzenia fakt, że wszelkie przejawy ograniczenia praw i wolności jednostki w sferze działalności gospodarczej muszą być uzasadnione ${ }^{17}$. Stąd też kryminalizację patologii gospodarczych nowego typu powinno poprzedzać przeprowadzenie bilansu zysków i strat, tak aby ujemne konsekwencje wprowadzenia określonej regulacji karnogospodarczej nie przeważały nad negatywnymi konsekwencjami kryminalizowanej patologii ${ }^{18}$.

Zasygnalizowane powyżej jedynie skrótowo zagadnienia stanowią o potrzebie ostrożnej kryminalizacji rynku finansowego, zwłaszcza w odniesieniu do pojawiających się nowych, często innowacyjnych form funkcjonowania w tym obszarze. Jednym ze stosunkowo nowych zjawisk na rynku finansowym, a przynajmniej takim, które zyskało rozgłos w ostatnich latach, jest fenomen tzw. shadow banking. W polskiej terminologii prawniczej termin ten tłumaczony jest jako bankowość równoległa ${ }^{19}$, równoległy system bankowy ${ }^{20}$, bankowość ukrycia (ukryta) ${ }^{21}$ czy bankowość cienia $^{22}$. Mianem tym określa się podmioty działające poza tradycyjnym systemem bankowym, świadczące usługi podobne do czynności banko-

15 Por. O. Górniok, op. cit., s. 55-56; J. Błachut, A. Gaberle, K. Krajewski, Kryminologia, Gdańsk 2004, s. 295.

16 W literaturze wskazuje się bowiem słusznie, że w grę wchodzić mogą także straty niematerialne wykraczające poza sferę życia gospodarczego (J. Błachut, A. Gaberle, K. Krajewski, op. cit., s. 295-296).

17 Zob. K. Wojtyczek, Granice ingerencji ustawodawczej w sfere praw człowieka w Konstytucji RP, Kraków 1999, s. 78; L. Gardocki, Zagadnienia teorii kryminalizacji, Warszawa 1990, s. 109-116.

18 R. Zawłocki, Kryminalizacja obrotu gospodarczego w Polsce..., s. 220.

19 J. Bąk, A. Stepanów, Europejskie prawo finansowe, Warszawa 2013, s. 111.

20 Ibidem.

21 J.K. Solarz, Shadow banking: systemowa innowacja finansowa, Łódź-Warszawa 2014, s. 9.

22 M. Olszak, Recenzja książki W. Szpringera, Instytucje nadzoru w sektorze finansowym. Kierunki rozwoju, Warszawa 2014, ss. 279, „IKAR” 2014, nr 5, s. 9; W. Gadomski, Shadow banking, czyli kto jest bankiem, a kto udaje, https://www.nbportal.pl/wiedza/ artykuly/finanse/shadow_banking (dostęp: 2 listopada 2017).

Nowa Kodyfikacja Prawa Karnego 46, 2017

(C) for this edition by CNS 
wych $^{23}$. Brak reglamentacji tej działalności i niepodleganie nadzorowi podmiotów funkcjonujących w tym obszarze prowokować mogą do zadania pytania o możliwe karnoprawne implikacje bankowości równoległej.

Przedmiotem artykułu jest analiza shadow banking z perspektywy polskiego prawa karnego gospodarczego. Analizie poddana zostanie możliwość karnoprawnej kwalifikacji bezprawnych zachowań podmiotów sektora bankowości równoległej w oparciu o istniejące regulacje prawne. Zadane zostanie także pytanie o ewentualną celowość, konieczność i racjonalność wprowadzenia nowych lub zmodyfikowania istniejących regulacji karnoprawnych.

\section{Uwagi szczegółowe}

\subsection{Shadow banking - perspektywa definicyjna}

Fenomen shadow banking wbrew pozorom nie jest zjawiskiem nowym. Choć termin ten powstał kilka lat temu, samej genezy powstania bankowości równoległej upatruje się w końcu lat 60 . XX w. w $\mathrm{USA}^{24}$, a niektórzy początki bankowości cienia dostrzegają w jeszcze wcześniejszym okresie $^{25}$. Za twórcę terminu shadow banking uważa się P. McCulleya, amerykańskiego ekonomistę, który wskazał, że obejmuje on najróżniejsze podmioty niebankowego pośrednictwa inwestycyjnego, przedsiębiorstwa i struktury ${ }^{26}$. Z kolei w zaleceniach Komitetu Stabilności Finansowej dotyczących shadow banking ${ }^{27}$ wskazano, że fenomen ten odnosi się do pośrednictwa kredytowego dotyczącego podmiotów i działań dokonywanych poza regularnym systemem bankowym. Problematyka powyższa

23 B. Paxford, [w:] Prawo bankowe. Komentarz, red. H. Gronkiewicz-Waltz, Warszawa 2013; idem, Komentarz do art. 2, teza 8, SIP Legalis.

24 A. Alińska, Shadow banking jako element zrównoważonego rozwoju systemu finansowego, [w:] L. Dziawgo, L. Patrzałek, Finanse na rzecz zrównoważonego rozwoju. Gospodarka - etyka - środowisko, „Prace Naukowe Uniwersytetu Ekonomicznego we Wrocławiu" 2016, nr 437, s. 26.

25 J.K. Solarz, op. cit., s. 41-75.

26 https://www.pimco.com/en-us/insights/economic-and-market-commentary/global-central-bank-focus/teton-reflections (dostęp: 5 listopada 2017).

$27 \mathrm{http} / /$ www.financialstabilityboard.org/wp-content/uploads/r_111027a.pdf (dostęp: 2 listopada 2017).

Nowa Kodyfikacja Prawa Karnego 46, 2017

(C) for this edition by CNS 
była także przedmiotem zainteresowań Komisji Europejskiej. W marcu 2012 r. w Zielonej Księdze dotyczącej Równoległego Systemu Bankowego ${ }^{28}$ wskazała ona, że shadow banking jest związany z podmiotami działającymi poza normalnym systemem bankowym, zajmującymi się przyjmowaniem środków finansowych (o cechach przyjmowania depozytów), dokonywaniem transformacji terminów zapadalności lub transformacji płynności, przeprowadzaniem transferu ryzyka kredytowego czy stosowaniem dźwigni finansowej (bezpośredniej lub pośredniej), a nadto działania te (sekurytyzacja, pożyczka papierów wartościowych, transakcje repo) mogą stanowić istotne źródła finansowania podmiotów pozabankowych. Wśród zidentyfikowanych przez Komisję Europejską zagrożeń związanych z funkcjonowaniem równoległego systemu bankowego znalazły się: ryzyko masowego wycofywania wkładów przez klientów, nieograniczone (nienadzorowane) stosowanie dużych dźwigni finansowych, obchodzenie nadzoru regulacyjnego, możliwość wpływu kryzysu w instytucjach równoległego systemu bankowego na system bankowy. Nie oznacza to jednak, że nie dostrzega się pozytywnych aspektów funkcjonowania shadow banking: alternatywę dla depozytów bankowych i finansowania gospodarki, specjalizację finansowania, jak również dywersyfikację ryzyka oddalonego od systemu bankowego.

Granice i zakres shadow banking uzależnione są od stopnia rozwoju architektury konkretnego rynku finansowego, który wpływa na specyfikę bankowości równoległej w poszczególnych krajach ${ }^{29}$. Przykładowo, uważa się, że specyfika polskiego shadow banking polega na działalności firm pożyczkowych ${ }^{30}$. Jednakże brak jest jednolitości w definiowaniu bankowości równoległej. Wskazuje się, że ,aby opisać bankowość równoległą, stosuje się dwie metody. Pierwsza to układanie łamigłówki ze zidentyfikowanych fragmentów bankowości równoległej, podczas gdy druga, to jej określenie na zasadzie reszty" 31 . Twierdzenie to — jak się wydaje oddawać może istotę niejasności (rozmycia) pojęcia bankowości równoległej. W tradycyjnym ujęciu shadow banking stanowi element składowy

28 Zielona Księga. Równoległy System Bankowy, Bruksela, 19 marca 2012, COM (2012) 102 final.

29 A. Alińska, op. cit., s. 29.

30 Idem; K. Opolski et al., Sektor shadow banking w Polsce, Warszawa 2015, s. 52.

31 J.K. Solarz, op. cit., s. 192.

Nowa Kodyfikacja Prawa Karnego 46, 2017

(C) for this edition by CNS 
systemu finansowego, niepodlegający pełnej, a nawet częściowej kontroli, do którego zaliczane są podmioty znajdujące się poza tradycyjnym system bankowym, wykonujące działalność finansową oferowaną nie przez banki, lecz inne instytucje pośrednictwa finansowego ${ }^{32}$. Bankowość równoległą określa się także mianem innowacji finansowej, a ściślej — innowacji rzeczowej (typ instytucji i instrumentów finansowych), innowacji czynnościowej (instytucjonalizacja bankowości równoległej jako alternatywy wobec bankowości depozy towo-kredytowej) oraz innowacji atrybutowej (zmiana reguł gry rynkowej) ${ }^{33}$. W fenomenie bankowości cienia upatruje się również emitenta pieniądza prywatnego wspieranego przez prywatną sieć bezpieczeństwa finansowego ${ }^{34}$.

\subsection{Shadow banking a parabanki}

Trudno nie dostrzec kontrowersji powstających wokół równoległego systemu bankowego ${ }^{35}$. Związane są one niewątpliwie $\mathrm{z}$ ostatnim globalnym kryzysem finansowym, jego przyczynami, jak również przekonaniem o konieczności zapewnienia bezpieczeństwa i stabilności, budowanie zaufania do systemu finansowego oraz ochrony jego nieprofesjonalnych uczestników. Niekiedy bowiem działalność podmiotów bankowości równoległej wręcz utożsamiana jest z działalnością parabankową ${ }^{36}$. Zresztą pojęcie parabanku, podobnie jak shadow banking, również nie zostało w literaturze precyzyjnie wyjaśnione ${ }^{37}$. W starszej literaturze pojęcie parabanku nacechowane było pejoratywnie i mianem tym określano podmioty wykonujące czynności bankowe bez zezwolenia. W nowszej literaturze z kolei wskazuje się, że status parabanku przysługuje podmiotom innym niż banki, które wykonują działalność depozytową jako

32 A. Alińska, op. cit., s. 29.

33 J.K. Solarz, op. cit., s. 38.

34 J. Kotyński et al., Dylematy światowego systemu gospodarki i finansów, Warszawa 2015, s. 92.

35 Zob. J.K. Solarz, op. cit., s. 145.

36 Ibidem, s. 10. Zob. np. D. Szymczak, Nowe zasady nadzoru nad shadow banking proponowane przez Unię Europejska we wspótpracy z Komitetem Stabilności Finansowej, [w:] XXV lat przeobrażén w prawie finansowym i prawie podatkowym - ocena dokonań i wnioski na przyszłość, red. Z. Ofiarski, Szczecin 2014, s. 861-869; K. Opolski et al., op. cit., s. 19; W. Gadomski, op. cit.

37 W. Srokosz, Instytucje parabankowe w Polsce, Warszawa 2011, s. 76.

Nowa Kodyfikacja Prawa Karnego 46, 2017

(C) for this edition by CNS 
działalność podstawową ${ }^{38}$. Na tle zasygnalizowanych wyżej rozbieżności pojawił się pogląd, zgodnie z którym na tle instytucji parabankowych shadow banking stanowią ,bardziej wyrafinowane instytucje finansowe"39, do których zaliczyć można niepodlegające nadzorowi finansowemu fundusze hedgingowe, fundusze rynku pieniężnego oraz strukturyzowane fundusze inwestycyjne (SIV). Wskazuje się także, że ,jąadro bankowości równoległej stanowią globalne, systemowo ważne instytucje finansowe oraz rynki hurtowe, międzybankowe" 40 .

\subsection{Kryminalizacja shadow banking w Polsce}

Jak można zaobserwować z pobieżnego tylko przeglądu definicji shadow banking oraz ich powiązań z działalnością parabankową, brak jest jednolitego podejścia do przedmiotowej problematyki w literaturze fachowej, zwłaszcza jej zakresu przedmiotowego. Wydaje się, że zakres tego pierwszego terminu jest znacznie szerszy, obejmuje także podmioty niezaliczane tradycyjnie do sektora bankowego (np. fundusze venture capital). Istotą shadow banking jest zasadniczy brak regulacji tego elementu sektora finansowego ${ }^{41}$. W konsekwencji, brak jest również regulacji karnogospodarczych stanowiących specjalną podstawę do karania tego fenomenu na rynku finansowym. Wszak zgodnie z ,tradycją” legislacyjną ostatnich lat praktycznie każda z ustaw regulujących funkcjonowanie określonych sfer życia gospodarczego zawiera grupę przepisów karnych (rzadziej przepis) kryminalizujących — najogólniej rzecz ujmując — naruszenie przepisów tej ustawy. Nie oznacza to jednak, że działalność podmiotów wykonujących czynności z zakresu bankowości równoległej nie może realizować ustawowych znamion przestępstw stypizowanych w istniejących już przepisach karnogospodarczych. W dużej mierze działalność taka wykonywana jest bezprawnie, realizować może bowiem znamiona przestępstw polegających na naruszeniu reglamentacji podej-

38 Ibidem, s. 77-81; W. Srokosz, Działalność depozytowa jako podstawowa cecha instytucji parabankowej, „Monitor Prawa Bankowego” 2013, nr 6, s. 54-65; A. Jurkowska-Zeidler, Definicja parabanku, „Monitor Prawa Bankowego” 2013, nr 6, s. 29.

39 W. Gadomski, op. cit.

40 J.K. Solarz, op. cit., s. 10.

41 Zob. jednak J. Kotyński et al., op. cit., s. 96. Por. także W. Szpringer, Nowe technologie a sektor finansowy, Warszawa 2017, s. 11-13.

Nowa Kodyfikacja Prawa Karnego 46, 2017

(C) for this edition by CNS 
mowania działalności na rynku finansowym ${ }^{42}$. Na potrzeby dalszych analiz fenomen shadow banking będzie ujmowany w najszerszym ujęciu i obejmie firmy ${ }^{43}$ : pożyczkowe, leasingowe, faktoringowe, inwestycyjne, lokacyjno-inwestycyjne oraz venture capital.

W literaturze fachowej wskazuje się, że specyfika polskiego systemu finansowego powoduje, iż znaczną część rodzimego shadow banking stanowią podmioty świadczące usługi pożyczkowe ${ }^{44}$. Zresztą w ramach prezentowanych analiz otoczenia prawnego bankowości równoległej wprost wskazuje się na przepis art. 171 ust. 1 ustawy z dnia 29 sierpnia 1997 r. - Prawo bankowe ${ }^{45}$ jako główny instrument zapobiegania i zwalczania bezprawnej działalności bankowości cienia ${ }^{46}$. W konsekwencji, w przypadku gdy podmioty bankowości równoległej naruszą monopol banków do wykonywania czynności depozytowo-kredytowych, w grę może wejść ich odpowiedzialność za przestępstwo określone w przepisie art. 171 ust. 1 PrB. Stanowi ono przestępstwo powszechne, polegające na prowadzeniu bez zezwolenia działalności opartej na gromadzeniu środków pieniężnych innych osób fizycznych, osób prawnych lub jednostek organizacyjnych niemających osobowości prawnej, w celu udzielania kredytów, pożyczek pieniężnych lub obciążania ryzykiem tych środków w inny sposób. Stąd też dla kryminalizacji zachowania konieczne jest, aby działalności depozytowej (gromadzeniu środków pieniężnych) towarzyszyła działalność kredytowa (obciążanie ryzykiem środków powierzonych). Z uwagi na wprowadzenie tzw. klauzuli odpowiedzialności zastępczej podstawę odpowiedzialności osoby fizycznej działającej w imieniu lub $\mathrm{w}$ interesie osoby prawnej lub jednostki organizacyjnej niemającej osobowości prawnej stanowi przepis art. 171 ust. 3 PrB. Przestępstwo to jest zagrożone karą grzywny do 10000000 zł i karą pozbawienia wolności do lat 10. Stwierdzenie faktu popełnienia czynu zabronionego z art. 171 ust. 1 oraz 3 PrB przez reprezentanta podmiotu zbiorowego stanowić może również podstawę odpowiedzialności takiego podmiotu na podstawie ustawy

42 Zob. szerzej P. Ochman, Karnoprawna ochrona podejmowania działalności finansowej..., s. 161-173.

43 K. Opolski et al., op. cit., s. 52. Zob. także J.K. Solarz, op. cit., s. 194-199.

44 A. Alińska, op. cit., s. 29.

45 Dz.U. z 2017 r., poz. 1876 z późn. zm.

46 K. Opolski et al., op. cit., s. 99.

Nowa Kodyfikacja Prawa Karnego 46, 2017

(C) for this edition by CNS 
z dnia 28 października 2002 r. o odpowiedzialności podmiotów zbiorowych za czyny zabronione pod groźbą kary ${ }^{47}$ (art. 16 ust. 1 pkt 1 lit. d).

Działalność podmiotów sektora bankowości równoległej może naruszać przepisy ustawy z dnia 19 sierpnia $2011 \mathrm{r}$. o usługach płatniczych ${ }^{48}$. Jakkolwiek usługi płatnicze dotyczą rozliczania transakcji i polegają na umożliwieniu płatnikowi przekazania, a odbiorcy — odebrania środków ${ }^{49}$, to jednak w grę wejść może odpowiedzialność za przestępstwo określone w przepisie art. 150 ust. 1 UPU. Stanowi ono przestępstwo powszechne polegające na prowadzeniu działalności w zakresie świadczenia usług płatniczych lub w zakresie wydawania pieniądza elektronicznego przez podmiot do tego nieuprawniony. Katalog usług płatniczych określony został w przepisie art. 3 ust. 1 UPU. Zaliczyć do nich można: przyjmowanie wpłat gotówki i dokonywanie wypłat gotówki z rachunku płatniczego oraz wszelkie działania niezbędne do prowadzenia rachunku; wykonywanie transakcji płatniczych, w tym transferu środków pieniężnych na rachunek płatniczy u dostawcy użytkownika lub u innego dostawcy przez wykonywanie usług polecenia zapłaty, w tym jednorazowych poleceń zapłaty, przy użyciu karty płatniczej lub podobnego instrumentu płatniczego lub przez wykonywanie usług polecenia przelewu, w tym stałych zleceń; wykonywanie wskazanych wyżej transakcji płatniczych w ciężar środków pieniężnych udostępnionych użytkownikowi z tytułu kredytu; wydawanie instrumentów płatniczych; umożliwianie wykonania transakcji płatniczych, zainicjowanych przez akceptanta lub za jego pośrednictwem, instrumentem płatniczym płatnika, w szczególności na obsłudze autoryzacji, przesyłaniu do wydawcy karty płatniczej lub systemów płatności zleceń płatniczych płatnika lub akceptanta, mających na celu przekazanie akceptantowi należnych mu środków, z wyłączeniem czynności polegających na jej rozliczaniu i rozrachunku w ramach systemu płatności w rozumieniu ustawy o ostateczności rozrachunku (acquiring); świadczenie usługi przekazu pieniężnego; wykonywanie transakcji płatniczych, w przypadku których zgoda płatnika na wykonanie transakcji udzielana jest przy użyciu urządzenia telekomunikacyjnego, cyfrowego

47 Dz.U. z 2016 r., poz. 1541 z późn. zm. (dalej jako: OPZU).

48 Dz.U. z 2017 r., poz. 2003 z późn. zm. (dalej jako: UPU).

49 M. Grabowski, Ustawa o ustugach platniczych. Komentarz, Warszawa 2012; idem, Komentarz do art. 3, teza 3.

Nowa Kodyfikacja Prawa Karnego 46, 2017

(c) for this edition by CNS 
lub informatycznego, a płatność przekazywana jest dostawcy usług telekomunikacyjnych, cyfrowych lub informatycznych, działającemu jedynie jako pośrednik pomiędzy użytkownikiem zlecającym transakcję płatniczą a odbiorcą. Jak więc można zaobserwować, UPU nie obejmuje stosunku prawnego, który stanowi podstawę realizacji usług płatniczych, jak również konstrukcji prawnej stanowiącej podstawę dokonywanych rozliczen ${ }^{50}$. Z uwagi na wprowadzenie tzw. klauzuli odpowiedzialności zastępczej podstawę odpowiedzialności osoby fizycznej działającej w imieniu lub w interesie osoby fizycznej, osoby prawnej lub jednostki organizacyjnej niebędącej osobą prawną, której ustawa przyznaje zdolność prawną, stanowi przepis art. 151 ust. 3 UPU. Przestępstwo to jest zagrożone karą grzywny do 5000000 zł albo karą pozbawienia wolności do lat 2 bądź obiema tymi karami łącznie. Stwierdzenie faktu popełnienia czynu zabronionego z art. 151 ust. 1 lub 3 UPU przez reprezentanta podmiotu zbiorowego nie będzie jednak stanowić podstawy odpowiedzialności takiego podmiotu na podstawie OPZU z uwagi na brak jego wskazania w przepisie art. 16 tej ustawy.

Ze względu na fakt, że działalność podmiotów sektora shadow banking nie jest ograniczona wyłącznie do przyjmowania depozytów, ale obejmuje także inne czynności pozwalające na transformację terminów zapadalności, transformację płynności, transfer ryzyka kredytowego czy stosowanie dźwigni finansowej, w grę może również wejść odpowiedzialność z tytułu przestępstwa określonego w przepisie art. 178 ustawy z dnia 29 lipca 2005 r. o obrocie instrumentami finansowymi ${ }^{51}$. Stanowi ono przestępstwo powszechne, polegające na prowadzeniu działalności w zakresie obrotu instrumentami finansowymi bez wymaganego zezwolenia lub upoważnienia zawartego $\mathrm{w}$ odrębnych przepisach albo bez uprawnienia nadanego w inny sposób określony w ustawie. Brak wskazania przez ustawodawcę, o jaką konkretnie aktywność chodzi, prowadzić może do wniosku, że kryminalizowaną działalność w zakresie obrotu instrumentami finansowymi stanowi dokonywanie czynności zarówno faktycznych, jak i prawnych, których przedmiot stanowią instrumenty finansowe ${ }^{52}$.

50 Ibidem.

51 Dz.U. z 2017 r., poz. 1768 z późn. zm. (dalej jako: OIFU).

52 P. Ochman, Karnoprawna ochrona rynku kapitałowego: przepisy karne ustaw polskiego rynku kapitatowego, Londyn 2014, s. 61.

Nowa Kodyfikacja Prawa Karnego 46, 2017

(C) for this edition by CNS 
OIFU nie zawiera tzw. klauzuli odpowiedzialności zastępczej, a w konsekwencji brak jest wyraźnej podstawy pociągnięcia do odpowiedzialności osoby fizycznej działającej w imieniu lub w interesie innej osoby fizycznej, osoby prawnej czy jednostki organizacyjnej niemającej osobowości prawnej $^{53}$. Przestępstwo to jest zagrożone karą grzywny do $5000000 \mathrm{zl}$. Stwierdzenie faktu popełnienia czynu zabronionego z art. 178 FIU przez reprezentanta podmiotu zbiorowego stanowić może również podstawę odpowiedzialności takiego podmiotu na podstawie OPZU (art. 16 ust. 1 pkt 2 lit. b).

Działalność podmiotów sektora bankowości równoległej naruszać może przepisy ustawy z dnia 27 maja 2004 r. o funduszach inwestycyjnych i zarządzaniu alternatywnymi funduszami inwestycyjnymi ${ }^{54}$. Wszak shadow banking system obejmuje obok firm pożyczkowych, leasingowych czy faktoringowych także firmy inwestycyjne, lokacyjno-inwestycyjne oraz venture capital. Z uwagi na to w grę wejść może odpowiedzialność karna, zwłaszcza za przestępstwo z art. 287 ust. 1 FIU. Do istoty przestępstwa stypizowanego w przepisie art. 287 ust. 1 FIU, jako przestępstwo powszechne, należy wykonywanie działalności polegającej na lokowaniu w papiery wartościowe, instrumenty rynku pieniężnego lub inne prawa majątkowe aktywów osób fizycznych, osób prawnych lub jednostek organizacyjnych nieposiadających osobowości prawnej, zebranych w drodze propozycji zawarcia umowy, której przedmiotem jest udział w tym przedsięwzięciu, bez wymaganego zezwolenia lub wbrew warunkom określonym w ustawie. Chodzi zatem o naruszenie administracyjnych form reglamentacji w zakresie działalności lokacyjnej. Podstawą odpowiedzialności za wskazane przestępstwo osoby działającej w imieniu lub w interesie osoby prawnej lub jednostki organizacyjnej nieposiadającej osobowości prawnej jest z kolei przepis art. 287 ust. 2 FIU. Przestępstwo to jest zagrożone karą grzywny do 10000000 zł i karą pozbawienia wolności do lat 5. Stwierdzenie faktu popełnienia czynu zabronionego z przepisu art. 287 ust. 1 i 2 FIU przez reprezentanta podmiotu zbioro-

53 Nie oznacza to jednak, że ustawowe znamiona przestępstwa z art. 178 OIFU nie obejmują takich przypadków.

54 Dz.U. z 2016 r., poz. 1896 z późn. zm. (dalej jako: FIU). 
wego nie będzie jednak stanowić podstawy odpowiedzialności takiego podmiotu na podstawie OPZU z uwagi na brak jego wskazania w przepisie art. 16 tej ustawy.

\section{Podsumowanie}

Działalność podmiotów sektora shadow banking nie musi stanowić domeny parabanków. Aktywność taka nie musi również stanowić działalności bezprawnej, a zwłaszcza przestępczej. Jeśli działalność bankowości cienia jest zgodna z prawem, może stanowić czynnik napędzający rynek finansowy, jednak w przypadku gdy narusza prawo, stanowi jeden z przejawów tzw. nielegalnych rynków ${ }^{55}$. Wtedy też do specyficznych (szczególnych) źródeł patologii w tym zakresie zaliczyć można ${ }^{56}$ : ingerencję państwa, dysfunkcjonalność rynków finansowych, arbitraż prawny, a także negatywny efekt zewnętrzny funkcjonowania tego elementu systemu finansowego.

Ze względu na fakt, że zjawisko shadow banking jest w polskiej rzeczywistości społeczno-gospodarczej wciąż nowe, brak jest specjalnych regulacji odnoszących się bezpośrednio do tego fenomenu. Regulacja prawna bankowości równoległej następuje zasadniczo na punktach stycznych z reglamentowaną działalnością na rynku finansowym, zwłaszcza w zakresie ochrony praw konsumenta, wymogów kapitałowych lub norm płynności czy nadzoru systemowego ${ }^{57}$.

Wydaje się, że na obecnym etapie diagnozy granic i zakresu bankowości równoległej w Polsce jej kryminalizacja nie jest zabiegiem pożądanym, zwłaszcza że aktualnie obowiązujące regulacje prawne pozwalają na karanie bezprawnych przejawów funkcjonowania bankowości równoległej. W tym obszarze mogą bowiem znaleźć zastosowanie zwłaszcza przepisy karne typizujące przestępstwa bezprawnego: wykonywania działalności

55 B. Gadecki, Parabanki - aspekty prawnokarne i kryminologiczne, [w:] Zagrożenia w sektorze bankowym. Analiza kryminalna zjawisk i możliwości przeciwdziałania, red. P. Chlebowicz, Olsztyn 2013, s. 78.

56 J.K. Solarz, op. cit., s. 145.

57 W. Szpringer, Shadow banking jako nowy obszar regulacji prawnej, „Monitor Prawa Bankowego” 2013, nr 6, s. 39; J. Kotyński et al., op. cit., s. 96. 
bankowej (art. 171 ust. 1 i 3 PrB), prowadzenia działalności w zakresie świadczenia usług płatniczych lub w zakresie wydawania pieniądza elektronicznego (art. 150 ust. 1 i 3 UPU), prowadzenia działalności w zakresie obrotu instrumentami finansowymi (art. 178 FIU), czy też prowadzenia działalności lokacyjnej (art. 287 ust. 1 i 2 FIU). Ich analiza prowadzi do wniosku, że brak jest spójności zarówno w zakresie modelu karania (sposobu opisu zabronionego zachowania), jego zakresu podmiotowego (niejednolitość i różnorodność klauzul odpowiedzialności zastępczej), jak i dolegliwości (brak spójności rodzajów kar oraz ich wysokości), ale także w zakresie odpowiedzialności podmiotów zbiorowych. Mając na uwadze powyższe, wskazać należy, że dopiero dalsza obserwacja fenomenu bankowości równoległej, a zwłaszcza modelu jego regulacji prawnej, może stanowić podstawę do ewentualnej dyskusji w przedmiocie zmiany zakresu oraz intensywności kryminalizacji sektora shadow banking w Polsce.

\section{Shadow banking and criminal economic law}

\section{Summary}

The article attempts to answer the question whether in the current legal state the activity of shadow banking in Poland is subject to criminalization. The limits and scope of criminalization of entities of this element of the financial market is also presented. The reflections are supplemented by a review of the definition of parallel banking, and also discussed the economic crimes that can be traced back to parallel banking activities.

Keywords: shadow banking, criminal economic law, prawo karne gospodarcze, parallel banking, illegal financial activity.

Nowa Kodyfikacja Prawa Karnego 46, 2017

(C) for this edition by CNS 